\title{
SELF - EFFICACY REMAJA PECANDU NARKOBA DI RUMAH SEHAT ORBIT MARGOREJO INDAH UTARA SURABAYA
}

\author{
Aristina Halawa* \\ STIKes William Booth Surabaya Jl.Cimanuk No.20 Surabaya 60241 \\ halawaaristina@yahoo.co.id
}

\begin{abstract}
ABSTRAK
Penyalahgunaan narkoba dikalangan remaja yang menimbulkan dampak terhadap psikologis remaja yang berakibat menurunnya self-efficacy atau rendahnya keyakinan terhadap kemampuan yang dimiliki. Tujuan penelitian ini adalah untuk mengetahui Gambaran SelfEfficacy Pada Remaja Pecandu Narkoba Di Rumah Sehat Orbit Margorejo Indah Utara Surabaya. Desain penelitian yaitu menggunakan desain deskriptif, dengan jumlah populasi 12 responden, dan jumlah sampel 12 responden remaja pecandu narkoba. Tehnik sampling yang digunakan yaitu Total sampling. Instrumen penelitian menggunakan kuesioner dalam pengambilan data. Analisa data menggunakan distribusi frekuensi. Diharapkan self efficacy Remaja Pecandu Narkoba ini dapat menjadi gambaran agar menjadi perhatian bagi bagian yang terkait untuk terus memperhatikan remaja pecandu Narkoba sehingga mereka dapat ditingkatkan self efficacynya.
\end{abstract}

\section{Kata Kunci : self-efficacy, remaja pecandu narkoba}

\section{ABSTRACT}

Drug abuse among adolescents has a psychological impact on adolescents which results in decreased self-efficacy or low confidence in their abilities. The purpose of this study was to determine the description of self-efficacy in adolescent drug addicts at Margorejo Indah Utara Orbit Healthy Home in Surabaya. The research design is using descriptive design, with a total population of 12 respondents, and a sample of 12 teenage drug addict respondents. The sampling technique used is total sampling. The research instrument used a questionnaire in data collection. Data analysis uses frequency distribution. It is expected that the self efficacy of adolescent drug addicts can be an illustration so that it becomes a concern for the relevant section to continue to pay attention to adolescent drug addicts so that they can improve their self efficacy.

Keywords: self-efficacy, adolescent drug addicts 


\section{PENDAHULUAN}

Penyalahgunaan narkotika dan obat obatan terlarang (narkoba) di Indonesia masih marak terjadi bahkan sudah dijadikan trend baik bagi kalangan remaja dan masih menjadi masalah utama yang perlu diperhatikan dan perlu ditindaklanjuti karena penyimpangan ini sangat tidak sesuai dengan norma dan nilai yang berlaku dalam masyarakat Indonesia. Penyalahgunaan narkoba tidak hanya berdampak pada kesehatan fisik para remaja yang menyalahgunakannya namun juga mengancam kelangsungan hidup masa depan penggunanya dan bahkan ini menjadi masalah yang serius bagi masa depan bangsa dan negara mengingat remaja adalah generasi penerus bangsa. Papalia dan Old (2001) menjelaskan bahwa masa remaja merupakan masa transisi fase perkembangan antara masa anak - anak menuju masa dewasa. Dimana pada fase ini ditandai oleh perubahan fisik, emosional, intelektual, seksual dan sosial. Perubahan tersebut akan berdampak pada pencarian jati diri seorang remaja, pemberontakan, pendirian yang labil, minat yang berubah - ubah, mudah terpengaruh mode, konflik dengan orang tua, dorongan ingin tahu dan coba - coba yang kuat, pergaulan yang luas dengan teman sebaya mereka akan lebih sering menghabiskan waktu dengan teman temannya. Dimana teman sebaya juga memiliki fungsi pekembangan yang juga dapat membawa pengaruh negatif. Dampak pengaruh negatif yang dialami remaja adalah salah satunya penyalahgunaan narkoba. Maudy Pritha (2017) dalam jurnal PenyalahgunaanNarkoba di Kalangan Remaja menjelaskan bahwa beberapa faktor penyebab remaja menggunakan narkoba adalah ingin terlihat gaya pemakai akan merasa dirinya menjadi lebih berani, keren, percaya diri, faktor lainnya menggunakan narkoba yaitu narkotika dapat menghilangkan rasa sakit, coba coba atau rasa ingin tahu yang tinggi, melupakan masalah/ beban stress, menonjolkan sisi pemberontakan, mencari tantangan, dan merasa dewasa. Remaja yang menyalahgunakan narkoba akan mempengaruhi susunan saraf, narkoba menimbulkan perilaku, perasaan, persepsi dan kesadaran bahkan dapat menimbulkan efek yang membahayakan tubuh. Psikologis remaja pengguna narkoba juga akam mengalami masalah salah satunya adalah menurunnya self - efficacy pada remaja tersebut. Self - efficacy mengacu pada keyakinan individu mengenai kemampuan dirinya dalam melakukan tugas atau tindakan yang diperlukan untuk mencapai hasil tertentu. (Bandura, 1986). Schultz (1994) menegaskan bahwa self efficacy sebagai perasaan seseorang terhadap kecukupan, efisiensi dan kemampuannya dalam mengatasi kehidupan. Apabila self - efficacy yang dimiliki tinggi, ia akan terus meningkatkan upaya untuk dapat menyelesaikan masalah yang dihadapi. Individu dengan self efficacy yang rendah akan menimbulkan masalah yang mengarahkan individu menghindari lingkungan dan kegiatan yang akan memperlambat perkembangan, menghalangi usaha dan menyebabkan individu mudah putus asa. Rendahnya self efficacy yaitu akan memicu para pecandu yang telah lepas dari narkoba akan mengalami relaps, ini dibuktikan melalui penelitian yang dilakukan oleh Ibrahim, Kumal, dan Samah (Rozi, 2016) dalam jurnal Pengaruh Pelatihan Self - Efficacy Terhadap Kecenderungan Relaps Pada Pecandu Narkoba.Intan Aghita (2018) menegaskan dalam penelitian Hubungan Antara Self-Efficacy Dan Kecenderungan Relapse Pada Pecandu Narkoba Yang Menjalani Rehabilitasi bahwa self - efficacy memberikan pengaruh sebesar 35,2\% terhadap kecenderungan relaps pada pecandu narkoba yang menjalani rehabilitasi. Masalah dari rendahnya self - efficacy yang ditemukan di panti rehabilitasi Rumah Sehat Orbit Surabaya adalah beberapa remaja mengatakan mereka tidak 
mempunyai keyakinan dapat lepas/sembuh dari jeratan narkoba, mereka tidak yakin dapat melanjutkan kehidupan selanjutnya meskipun sudah lepas dari narkoba, mereka beranggapan tidak dapat lagi bisa dipercaya oleh masyarakat karena sebagai mantan pecandu narkoba, mereka tidak punya keyakinan untuk melanjutkan sekolah atau mendapatkan perkerjaan. Bahkan ada remaja yang mengatakan mereka akan kembali menggunakan narkoba setelah masa rehabilitasi selesai.

Indonesia dalam keadaan gawat narkoba, penelitian yang dilakukan Badan Narkotika Nasional (BNN) di perkirakan jumlah penyalahgunaan obat - obatan terlarang ini mencapai 34.296 kasus di tahun 2015. Jumlah mengalami peningkatan sebesar 19,62 \% atau meningkat sebanyak 6.729 kasus pada tahun 2016 dengan total kasus tahun 2016 ini sebanyak 41.025 kasus. Di tahun 2017 kembali terjadi peningkatan yang signifikan yaitu sebesar 46.537 kasus. Dari data tersebut menunjukkan peningkatan kasus narkoba dari tahun ke tahun yang memprihatinkan. Menurut Komisioner Bidang Kesehatan KPAI, Sitti Hikmawatty, 2018 (dalam okezone.com) mengatakan dari 87 juta populasi anak di Indonesia sebanyak 5,9 juta diantaranya adalah pengguna narkoba. BNN mencatat pada tahun 2016 Provinsi Jawa Timur menyumbang sebesar $27,3 \% \quad$ (238.280) remaja yang menggunakan narkoba. BNN Kota Surabaya Singgih mengungkapan sepanjang Januari - November 2016 sebanyak 200 pelajar Kota Surabaya positif konsumsi narkoba. Jumlah tersebut meningkat dibanding tahun 2015 sebanyak 65 pelajar. Berdasarkan data yang penulis dapatkan pada tanggal 13 Februari 2019 di Rumah Sehat Orbit Margorejo Indah Utara Surabaya, terdapat 12 orang yang ketergantungan narkoba dan menjalani rawat inap dan sekitar 1.000 orang menjalani rawat jalan. Terdapat 10 orang rawat inap dari kalangan remaja. Penulis melakukan wawancara kepada 10 remaja pecandu narkoba, 1 remaja mengatakan ia sangat yakin dan ingin sekali lepas/sembuh dari barang haram tersebut, 9 remaja mengatakan mereka tidak yakin dapat lepas/sembuh dari pengaruh narkoba, mereka tidak mempunyai keyakinan untuk dapat melanjutkan kehidupan selanjutnya, bahkan setelah masa rehabilitasi selesai mereka akan tetap menggunakan narkoba. Dari data tersebut dapat kita lihat bahwa 90\% para pecandu narkoba memiliki selfefficacy yang rendah walaupun mereka sudah menjalani masa rehabilitasi.

Jimmy Simanguson (2015) dalam

Jurnal Penyalahgunaan Narkoba di Kalangan Remaja, mengatakan remaja merupakan objek yang secara emosional masih labil, masa perkembangan anakanak menuju dewasa dimanan masalah utama pada remaja adalah pencarian jati diri, sehingga sangat rentan untuk terpengaruh menggunakan narkoba. Mulai dari rasa ingin tahu, ingin terlihat keren, mau coba-coba, ikut-ikutan teman, rasa solidaritas grup yang kuat dan memilih lingkungan pergaulan yang salah sampai dengan faktor keluarga yang kurang perhatian membuat remaja mudah terjerat dalam narkoba. Narkoba membawa efek efek negatif terhadap tubuh pemakai itu sendiri baik fisik, psikis, maupun sosial (BBNP, 2014). Mereka yang mengkonsumsi narkoba akan mengalami gangguan mental dan perilaku, sebagai akibat terganggunya sistem neuro transmitter (zat kimia di otak yang mehubungkan informasi antar sel saraf), maka dapat mengakibatkan teganggunya fungsi kognitif (alam fikiran), afektif (perasaan) dan perilaku (Hawari, 2010). Maindra Fauziannisa dan Mareyke Maritje (2013) mengatakan pecandu narkoba juga mengalami penurunan pada self efficacynya. Menurut Yong (Rachmawati, 2012: 18) self - efficacy yang tinggi akan menjadikan individu percaya bahwa ia dapat mengerjakan sesuatu atau suatu masalah sesuai dengan tuntutan situasi dan memiliki harapan yang realistik, self efficacy yang tinggi pada pecandu narkoba dapat mempengaruhi keberhasilan 
treatment saat menjalani poses rehabilitasi, mereka yang gagal dalam melaksanakan sesuatu, biasanya cepat mendapatkan kembali self-efficacy mereka setelah mengalami kegagalan tersebut. Individu dengan self - efficacy yang rendah akan tidak mampu / tidak yakin mengatasi masalah yang dihadapi, menghindari masalah tersebut, mudah menyerah, ragu pada kemampuan diri, sehingga mengarahkan individu ke dalam kondisi depresi. Self - efficacy yang rendah pada remaja pecandu narkoba akan memunculkan masalah diantaranya, mereka tidak mempunyai keyakinan untuk lepas/sembuh dari narkoba sehingga membuat mereka lama dalam proses penyembuhan. Mereka tidak yakin dapat melanjutkan kehidupan selanjutnya meskipun sudah lepas dari narkoba, mereka beranggapan tidak dapat lagi bisa dipercaya oleh masyarakat karena sebagai mantan pecandu narkoba, mereka tidak punya keyakinan untuk melanjutkan sekolah sehingga berpendidikan rendah akan membuat mereka sulit untuk mendapatkan pekerjaan menjadikan mereka pengangguran dan menjadi beban bagi keluarga. Mereka yang tidak memiliki apa - apa akan melakukan tindakan kejahatan/kriminal, seperti pencurian, penodongan dan perampokan untuk mendapatkan apa yang mereka inginkan termasuk membeli nakoba. Mereka akan merasa putus asa dengan keadaannya saat ini memicu mereka untuk kembali menggunakan narkoba sehingga akan menimbulkan dampak yang lebih buruk lagi bagi kesehatan karena efek dari zat zat narkoba akan memunculkan penyakit paru - paru, HIV/AIDS, sakit syaraf/sendi, dan hepatitis $\mathrm{C}$, bahkan mengancam nyawa pengguna narkoba yang mengalami overdosis. Dalam mengatasi rendahnya self - efficacy remaja pecandu narkoba dapat dilakukan dengan memberikan motivasi self - efficacy pada pecandu. Menurut Bandura (1997) Self-efficacy pribadi didapatkan, dikembangkan, atau diturunkan melalui suatu atau dari kombinasi dari empat sumber berikut: Mastery experience (pengalamanpengalaman tentang penguasaan), Social modeling (permodelan sosial), Social persuasion (persuasi sosial), Physical and emotional state (kondisi fisik dan emosi). Keempat metode diatas dapat dikombinasikan pelaksanaanya agar dapat meningkatkan self efficacy pecandu narkoba. Dalam penelitian ini peneliti ingin melihat bagaimana gambaran Self efficacy Remaja pecandu narkoba karena dengan mengetahui self efficacy remaja tersebut maka dapat diprediksi bagaimana perilaku mereka dalam mengetasi masalah mereka keluar dari kecanduan narkoba.

\section{METODE}

Berdasarkan tujuan penelitian, desain penelitian yang digunakan dalam penelitian ini adalah deskripstif yatu metode penelitian yang bertujuan untuk menjelaskan, memberi suatu nama, situasi atau fenomena dalam menemukan ide baru (Nursalam, 2003).

Penelitian ini bertujuan untuk mengetahui gamaran self efficacy remaja pecandu narkoba. Pada penelitian ini populasinya adalah seluruh pecandu narkoba di Rumah Sehat Orbit Surabaya yaitu sebanyak 12 remaja.

Sampel dalam penelitian ini adalah seluruh pecandu narkoba di rumah Sehat Orbit Surabaya sejumlah seluruh pecandu narkoba 12 orang sesuai dengan teknik sampling yang dipergunakan yaitu total sampling.

Pengambilan data tentang Self efficacy Remaja Pecandu Narkoba di Rumah Sehat Orbit Margorejo Indah Utara Surabaya dilakukan dengan menyebarkan kuisioner GSE modifikasi kepada responden setelah menandatangani lembar informed consent. Cara menilai tingkat self-efficacy pada pecandu narkoba mengggunakan kuesioner terdiri dari 4 indikator berupa 10 pertayaan. Jika pecandu bisa melakukan sesuai dengan indikator penelitian bila sangat setuju $=4$, setuju $=3$, tidak setuju $=$ 2 , dan sangat tidak setuju $=1$. 


\section{HASIL DAN PEMBAHASAN}

\section{Responden Berdasarkan Usia}

Tabel 1 Distribusi responden berdasarkan usia di Rumah Sehat Orbit Margorejo Indah Utara Surabaya

\begin{tabular}{llll} 
No. & Usia & $\begin{array}{l}\text { Jumlah } \\
\text { Responden }\end{array}$ & $\begin{array}{l}\text { Presentase } \\
(\%)\end{array}$ \\
\hline $\begin{array}{l}11-14 \\
\text { Tahun }\end{array}$ & - & $0 \%$ \\
\hline $\begin{array}{l}15-17 \\
\text { Tahun }\end{array}$ & 3 & $25 \%$ \\
\hline $\begin{array}{l}18-20 \\
\text { Tahun }\end{array}$ & 9 & $75 \%$ \\
\hline Total & 12 & $100 \%$ \\
\hline
\end{tabular}

Berdasarkan Tabel 1 dapat diketahui bahwa mayoritas responden berusia 18 20 Tahun sebanyak 9 responden $(75 \%)$

Responden Berdasarkan Jenis Kelamin

Tabel 2 Distribusi responden berdasarkan jenis kelamin di Rumah Sehat Orbit Margorejo Indah Utara Surabaya

\begin{tabular}{llll} 
No & $\begin{array}{l}\text { Jenis } \\
\text { Kelamin }\end{array}$ & $\begin{array}{l}\text { Jumlah } \\
\text { Responde } \\
\mathrm{n}\end{array}$ & $\begin{array}{l}\text { Presentas } \\
\mathrm{e}(\%)\end{array}$ \\
\hline 1. & Laki - laki & 9 & $75 \%$ \\
\hline $\begin{array}{l}\text { 2. } \\
\mathrm{n}\end{array}$ & 3 & $25 \%$ \\
\hline Total & 12 & $100 \%$ \\
\hline
\end{tabular}

Berdasarkan Tabel 2 dapat diketahui bahwa mayoritas jenis kelamin responden adalah laki - laki sebanyak 9 responden $(75 \%)$

\section{Responden Berdasarkan Pendidikan}

Tabel 3 Distribusi responden berdasarkan pendidikan di Rumah Sehat Orbit Margorejo Indah Utara Surabaya

\begin{tabular}{llll}
$\begin{array}{l}\text { No } \\
\text {. }\end{array}$ & Pendidikan & $\begin{array}{l}\text { Jumlah } \\
\text { Respond } \\
\text { en }\end{array}$ & $\begin{array}{l}\text { Presenta } \\
\text { se }(\%)\end{array}$ \\
\hline 1. & SD & 1 & $8,33 \%$ \\
\hline 2. & SMP & 7 & $58,34 \%$ \\
\hline 3. & SMA & 4 & $33,33 \%$ \\
\hline
\end{tabular}

\begin{tabular}{lll}
\hline $\begin{array}{l}\text { Diploma/Sarj } \\
\text { ana }\end{array}$ & - & $0 \%$ \\
\hline Total & 12 & $100 \%$ \\
\hline
\end{tabular}

Berdasarkan Tabel 3 dapat diketahui bahwa sebagian besar responden berpendidikan SMP sebanyak 7 responden $(58,34 \%)$.

\section{Responden Berdasarkan Pekerjaan}

Tabel 4 Distribusi responden berdasarkan pekerjaan di Rumah Sehat Orbit Margorejo Indah Utara Surabaya

\begin{tabular}{llll}
\hline $\begin{array}{l}\text { No } \\
\cdot\end{array}$ & Pekerjaan & $\begin{array}{l}\text { Jumlah } \\
\text { Responde } \\
\mathrm{n}\end{array}$ & $\begin{array}{l}\text { Presentas } \\
\mathrm{e}(\%)\end{array}$ \\
\hline 1. & PNS & - & $0 \%$ \\
\hline 2. & $\begin{array}{l}\text { Pegawai } \\
\text { Swasta }\end{array}$ & 1 & $8,33 \%$ \\
\hline 3. & $\begin{array}{l}\text { Wiraswast } \\
\text { a }\end{array}$ & 1 & $8,33 \%$ \\
\hline 4. & $\begin{array}{l}\text { Tidak } \\
\text { Bekerja }\end{array}$ & 10 & $83,34 \%$ \\
\hline \multicolumn{7}{l}{ Total } & 12 & $100 \%$ \\
\hline
\end{tabular}

Berdasarkan Tabel 4 dapat diketahui bahwa mayoritas responden tidak bekerja yaitu sebanyak 10 responden $(83,34 \%)$

\section{Responden Berdasarkan Lama Menggunakan Narkoba}

Tabel 5 Distribusi responden berdasarkan lama menggunakan narkoba di Rumah Sehat Orbit Margorejo Indah Utara Surabaya

\begin{tabular}{llll}
\hline No & $\begin{array}{l}\text { Lama } \\
\text { Menggunak } \\
\text { an Narkoba }\end{array}$ & $\begin{array}{l}\text { Jumlah } \\
\text { Responde }\end{array}$ & $\begin{array}{l}\text { Presenta } \\
\text { se }(\%)\end{array}$ \\
\hline 1. & 1 Tahun & - & $0 \%$ \\
\hline 2. & 2 Tahun & 4 & $33,33 \%$ \\
\hline 3. & $\begin{array}{l}\text { 3 Tahun } \\
\text { lebih }\end{array}$ & 8 & $66,67 \%$ \\
\hline Total & 12 & $100 \%$ \\
\hline
\end{tabular}

Berdasarkan Tabel 5 dapat diketahui bahwa sebagian besar responden lama 
menggunakan narkoba 3 Tahun / lebih yaitu sebanyak 8 responden $(66,67 \%)$

\section{Responden Berdasarkan Pertama Kali Menggunakan Narkoba}

Tabel 6 distribusi responden berdasarkan pertama kali menggunakan narkoba di Rumah Sehat Orbit Margorejo Indah Utara Surabaya

\begin{tabular}{llll}
\hline No & $\begin{array}{l}\text { Pertama } \\
\text { Kali } \\
\text { Menggunak } \\
\text { an Narkoba }\end{array}$ & $\begin{array}{l}\text { Jumlah } \\
\text { Responde }\end{array}$ & $\begin{array}{l}\text { Presenta } \\
\text { se (\%) }\end{array}$ \\
\hline 1. & Waktu SMP & 10 & $83,33 \%$ \\
\hline 2. & Waktu SMA & 2 & $16,67 \%$ \\
\hline 3. & $\begin{array}{l}\text { Waktu } \\
\text { Kuliah }\end{array}$ & - & $0 \%$ \\
\hline Total & 12 & $100 \%$ \\
\hline
\end{tabular}

Berdasarkan Tabel 6 dapat diketahui bahwa mayoritas responden pertama kali menggunakan narkoba waktu SMP yaitu sebanyak 10 responden $(83,33 \%)$

\section{Responden Berdasarkan Lama Tinggal Di Panti Rehabilitasi}

Tabel 7 Distribusi responden berdasarkan lama tinggal di panti rehabilitasi di Rumah Sehat Orbit Margorejo Indah Utara Surabaya

\begin{tabular}{|c|c|c|c|}
\hline No & $\begin{array}{l}\text { Lama } \\
\text { Tinggal Di } \\
\text { Panti } \\
\text { Rehabilitas } \\
\text { i } \\
\end{array}$ & $\begin{array}{l}\text { Jumlah } \\
\text { Responde } \\
\text { n }\end{array}$ & $\begin{array}{l}\text { Presentas } \\
\text { e }(\%)\end{array}$ \\
\hline 1. & $\begin{array}{lcc}1- & 4 \\
\text { Minggu } & \end{array}$ & 12 & $100 \%$ \\
\hline 2. & $\begin{array}{ccc}5- & 8 \\
\text { Minggu } & \end{array}$ & - & $0 \%$ \\
\hline 3. & $\begin{array}{l}9-12 \\
\text { Minggu }\end{array}$ & - & $0 \%$ \\
\hline 4. & $\begin{array}{ll}3- & 6 \\
\text { Bulan } & \\
\end{array}$ & - & $0 \%$ \\
\hline Tota & & 12 & $100 \%$ \\
\hline
\end{tabular}

Berdasarkan Tabel 7 dapat diketahui bahwa responden tinggal di panti rehabilitasi selama $1-4$ minggu yaitu sebanyak 12 responden (100\%)

Data Khusus

Data khusus dalam bab ini mengidentifikasi self efficacy Remaja Pecandu Narkoba di Rumah Sehat Orbit Margorejo Indah Utara Surabaya

\section{Distribusi Self - Efficacy pada remaja pecandu narkoba}

Tabel 8 Distribusi Self - Efficacy pada remaja pecandu narkoba di Rumah Sehat Orbit Margorejo Indah Utara Surabaya

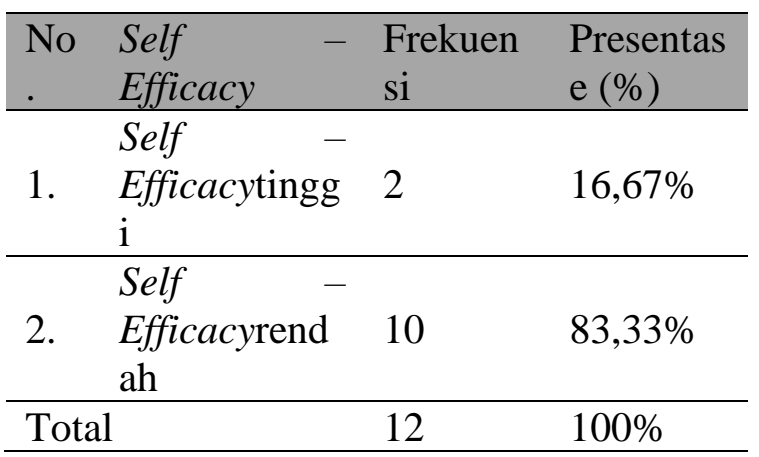

Berdasarkan tabel 8 didapatkan Self Efficacy pada remaja pecandu narkoba di Rumah Sehat Orbit Margorejo Indah Utara Surabaya bahwa sebagian besar responden memiliki Self - Efficacyrendah yaitu sebanyak 10 responden $(83,33 \%)$

\section{PEMBAHASAN}

Self - Efficacy pada remaja pecandu narkoba mayoritas memiliki Self-Efficacy yang rendah. Hal ini dapat dilihat pada tabel 8 dimana dari 12 responden terdapat 10 orang $(83,33 \%)$ yang memiliki Self Efficacy rendah dan 2 orang $(16,67 \%)$ memiliki Self - Efficacy tinggi. Menurut Bandura (1986) Self - Efficacy seseorang dapat dipengaruhi oleh beberapa faktor yaitu sifat tugas yang dihadapi, insentif eksternal,pengalaman pribadi, pengalaman orang lain dan dukungan sosial.Bila dikaitkan dengan penelitian ini maka ada 2 hal yang sesuai dengan pernyataan Bandura. Yaitu sifat tugas yang dihadapi 
dan pengalaman pribadi.Menurut Dhoni Wisnugroho (2010) yang menyatakan bahwa seorang pecandu narkoba yang dalam masa pemulihan memiliki Self Efficacy rendah. Hal ini terjadi karenaPara pecandu yang sedang menjalani masa pemulihan di dalam rumah rehabilitasi merasa bahwa semua orang akan tahu bahwa mereka adalah anak-anak yang bermasalah atau anak yang nakal. Dengan demikian mereka lebih banyak pasrah dan merasa tidak mampu untuk menjadi pribadi yang lebih baik karena merasa dibuang sebagai orang yang tidak berguna. Hal ini dapat dilihat dari cara pandang mereka terhadap tugas yang dihadapi, mereka memandang sesuatu menjadi sulit walaupun sebenarnya hal tersebut mudah untuk dilakukan, sehingga mereka tidak ada keinginan untuk mencobanya.

Cara pandang seseorang yang melihat suatu hal menjadi sulit ini berhubungan dengan apakah seseorang tersebut mempunyai pekerjaan atau mempunyai pengalaman bekerja atau belum bekerja. Seseorang yang mempunyai pekerjaan ia akan terbiasa dan mampu menyelesaikan tugasnya atau tanggung jawabnya, sehingga mudah dalam menghadapi suatu masalah/tugas. Sebaliknya seseorang yang tidak bekerja dan tidak mempunyai pengalaman bekerja akan kesulitan menghadi tugas/masalah. Pernyataan ini didukung data yang peneliti dapatkan pada tabel 5.4 responden pecandu narkoba di Rumah Sehat Orbit Margorejo Indah Utara Surabaya mayoritas tidak mempunyai pekerjaan yaitu sebanyak 10 responden $(83,34 \%)$, data ini menunjukan bahwa pecandu yang belum mempunyai pekerjaan atau tidak mempunyai pengalaman kerja mempengaruhi rendahnya self-efficacy pada responden dalam penelitian ini.

Pengalaman pribadi (Enative attainment), pengalaman pribadi yang tidak menyenangkan/kelam atau mengalami kegagalan akan menurunkan self-efficacy, karena mereka yang pernah gagal dan tidak mempunyai coping yang baik atas kegagalan yang menimpanya akan membuat mereka lamban dalam mencapai kembali self-efficacy nya.Pernyataan ini didukung pada tabel 5 dapat kita lihat data responden memiliki masa lalu dengan pengalaman kegagalan yang lama dimana mereka telah terjerumus menggunakan narkoba selama lebih dari 3 tahun yaitu sebanyak 8 responden $(66,67 \%)$, ini menunjukan bahwa responden yang telah lama menggunakan narkoba adalah mereka yang tidak mampu keluar dan mengatasi kegagalan sehingga akan melemahkan self-efficacy. Pengalaman orang lain(Vicarious experience), ini juga dapat mempengaruhi self-efficacy pada remaja pecandu nakoba, mereka yang melihat pengalaman kegagalanpecandu narkoba lain yang tidak dapat lepas dari narkoba dan bahkan mereka yang berakhir dipenjara, maka mereka juga akan ikut merasa tidak mampu lepas dari narkoba atau menjadi seseorang yang lebih baik dan mereka akan mengikuti jejak kehidupan seseorang tersebut yang mereka anggap memiliki masalah yang sama dengan mereka, hal ini akan melemahkan self-efficacy yang ia miliki. Dukungan sosial (social persuation) tidak adanya dukungan sosial ketika mereka berada di rumah rehabilitasi sebagai pecandu narkoba akan melemahkan self-efficacy mereka karena orang-orang, keluarga dan lingkungan yang menganggap mereka sebagai smpah yang dibuang dan tidak berguna membuat mereka semakin tidak mempunyai keyakinan atas kemampuannya. Keadaan fisiologis dalam situasi yang menekan dan ketika mengalami ketakutan yang besar, kecemasan, stress yang tinggi individu akan memiliki ekspektasi self-efficacy yang rendah.

Berdasarkan data yang diperoleh peneliti pada tabel 5.3 dapat diketahui bahwa responden pertama kali menggunakan narkoba mayoritas saat mereka mssuk pendidikan Sekolah Menengah Pertama (SMP) sebanyak 10 responden $(83,33 \%)$. Dimana berarti 
mereka mulai menggunakan narkoba ketika masa remaja awal. Anderson, (2009) menjelaskan bahwa karakteristik psikologis yang muncul pada remaja awal yaitu mereka krisis identitas, jiwa yang labil (keinginan yang berubah-ubah, mudah terpengaruh mode), coba-coba dan rasa ingin tahu yang kuat, lebih sering menghabiskan waktu dengan teman, berkurangnya rasa hormat terhadap orang tua, kadang-kadang berlaku kasar, menunjukan kesalahan orang tua, dan pemberontakan. Dimana pada fase ini ditandai oleh perubahan fisik, emosional yang tidak stabil, intelektual, seksual dan sosial yang tidak mendukung kondisi mereka akan berdampak pada pencarian jati diri seorang remaja. Sehingga pada fase ini remaja pecandu narkoba yang sudah memakai narkoba sejak SMP merasa tidak mampu untuk keluar dari jeratan narkoba walaupun tadinya hanya coba-coba akan mengalami penurunan Self - Efficacy. Dimana mereka sulit mendapatkan keyakinan dari dalam diri sendiri untuk sembuh dan melanjutkan kehidupan mendatang karena gejolak emosional mereka yang tidak stabil/labil sehingga mereka tidak dapat menentukan tujuan dalam hidupnya, dan akan tetap kembali menggunakan narkoba.

Berdasarkan data yang diperoleh peneliti pada tabel 5.3 dapat diketahui bahwa tingkat pendidikan responden yang menggunakan narkoba sebagian besar berpendidikan tingkat SMP yaitu sebanyak 7 responden $(58,34 \%)$. Pernyataan tersebut didukung oleh Fuad Kauma (1999) yang menyatakan bahwa pendidikan jelas sangat berpengaruh terhadap pembentukan kepribadian dan karakter remaja. Notoatmojdo (2003) mengatakan, seseorang yang berpendidikan tinggi diharapkan memiliki pengetahuan yang luas. Pendidikan diperlukan untuk mendapatkan informasi dalam hal menunjang kesehatan, sehingga dapat meningkatkan kualitas hidup termasuk dalam hal informasi tentang dampak dan bahaya narkoba terhadap kesehatan.
Apabila seseorang mendapatkan informasi yang benar tentang narkoba akan mencegah mereka menyalahgunakan obat - obatan terlarang tersebut. Para remaja pecandu narkoba yang memiliki pendidikan rendah akan mempengaruhi kepribadian dan karakter mereka, juga pengetahuan tentang penyalahgunaan narkoba sehingga mereka mudah terjerumus dalam jeratan narkoba.Self Efficacy juga merupakan salah satu aspek pengetahuan tentang diri atau selfknowledge yang paling berpengaruh dalam kehidupan manusia sehari-hari. Hal ini disebabkan Self - Efficacy yang dimiliki ikut mempengaruhi individu dalam menentukan tindakan yang akan dilakukan untuk mencapai suatu tujuan termasuk di dalamnya perkiraan berbagai kejadian yang akan dihadapi dan keyakinan seseorang dapat menguasai situasi dan mendapatkan hasil positif.

\section{SIMPULAN}

Berdasarkan penelitian yang telah dilakukan maka dapat disimpulkan sebagai berikut : Self-efficacy remaja pecandu narkoba Di Rumah Sehat Orbit Margorejo Indah Utara Surabaya, mayoritas responden memiliki Self-efficacy rendah sebanyak 10 responden $(83,33 \%)$.

\section{SARAN}

Dengan adanya penelitian ini diharapkan dapat menambah wawasan dan memberikan masukan bagi para staf yang ada di Rumah Sehat Orbit Margorejo Indah Utara Surabaya dalam meningkatkan Self-efficacy pada para pecandu

\section{DAFTAR PUSTAKA}

Amanda, Pritha et al. (2017). Penyalahgunaan Narkoba Di Kalangan Remaja (Adolescent Substance Abuse). Jurnal Penelitian \& PPMI. (4: 340 - 344) 
Anderson, L. W. \& Krathwohl, D. R. (2009). Pembelajaran dan Asesmen. Yogyakarta: Pustaka Belajar.

Ardianita.(2016) Studi Kasus Kehidupan Remaja Mantan Pecandu Narkoba. Artikel E-Journal. (1: 2 - 4 )

Bandura, A,1982. Self-efficacy mechanism in human agency. American Psychologist,37

Bandura, A,1986. Social foundations of thought and action. Englewood Cliffs, NJ: Prentice Hall.

Bandura, A,1992. Self-efficacy mechanism in psychobiologic functioning. In R. Schwarzer (Ed.), Self-efficacy: Thought control of action (pp.355394). Washington, DC: Hemisphere.

Bandura, A,2002. Self-efficacy. The exercise of control. New York: Freeman.

Bandura,A,1993. Perceived self-efficacy in cognitive development and functioning. Educational Psychologist,28,117-148.

BBN. (2015). Data Pengguna Narkoba Di Indonesia.

BNN Kota Surabaya. (2016). Data Remaja Pengguna Narkoba Di Surabaya.

BNN. (2017). Survei Nasional Penyalahgunaan Narkoba Di 34 Provinsi Tahun 2017. Pusat Penelitian Data dan Informasi BNN RI. Jakarta

Dhoni, Wisnugroho. 2010. Efikasi Diri Pada Pecandu Napza Dalam Proses Pemulihan Di Panti Sosial Pamardi Putra Sehat Mandiri Kalasan (Skripsi). Yogyakarta: Universitas Sanata Dharma Yogyakarta

Hawari, Dadang. 2010. Management Stress Cemas Dan Depresi. Jakarta: FKUI.
Kauma, Fuad. 1999. Sensasi Remaja Di Masa Puber. Kalam Mulia. Jakarta.

Notoatmojdo, Soekidjo. 2003. Pendidikan Dan Perilaku Kesehatan. Rineka Cipta. Jakarta.

Papalia, D. E., Old, S. W., Feldman, \& R. D. (2001). Perkembangan Manusia. Jakarta: Salemba Humanika.

Simangunsong, Jimmy. (2015). Penyalahgunaan Narkoba di Kalangan Remaja (Studi Kasus pada Badan Narkotika Nasional Kota Tanjungpinang). http://jurnal.umrah.ac.id/wpcontent/uploads/gravity_forms/1ec61c9cb232a03a96d0947c6478e52 5e/2015/09/E-jurnal-jimmy.pdf

Santrock, John W. (2007). Perkembangan Remaja. Alih Bahasa: Shinto B. Adelar dan Sherly Saragih. Jakarta: Penerbit Erlangga

Sitti Hikmawatty. .(2018). Anak Indonesia Pengguna Narkoba Semakin Meningkat, Okezone.com 15 Oktober

Schultz, D.P., \& Schultz, S.E. 1994. Psychology anda Work Today: An Introduction to Industrial and Organizational Psychology (6th Ed.). New York: MacMillan Publishing Company.

Rozi, H. F. (2016). Pengaruh Pelatihan Self Efficacy Terhadap KecenderunganRelapse Pada Pecandu Narkoba Di Balai Besar Rehabilitasi Badan NarkotikaNasional Bogor (Skripsi). Surakarta: Universitas Sebelas Maret 